\title{
ISLAM DAN PENDIDIKAN MADRASAH \\ DI FILIPINA
}

\section{ISLAM AND MADRASAH EDUCATION IN THE PHILIPPINES}

\section{Muhamad Murtadlo}

Puslitbang Pendidikan Agama dan Keagamaan Badan Litbang dan Diklat Kementerian Agama RI

Jl. MH Thamrin No. 06 Jakarta Timur Email: tadho25@gmail.com

\begin{abstract}
Madrasah in some Southeast Asian countries have a unique position, besides being as a place of teaching and educating Islam, it also performs the function of formal education. This study will examine the position of madrasah in one of the Southeast Asian countries, namely the Philippines. Madrasah in the Philippines was initially considered as part of the seeding the idea of separatist Moro people who want to separate from the Philippines. This research was conducted by literature study approach, with the aim of tracing the history and treatment of the Philippines government to this kind of educational institutions. The results showed that the Philippine government has started to accommodate madrasah in their national education system.
\end{abstract}

Key Words: Islam, madrasah, colonialism, Philippines

\begin{abstract}
Abstrak
Madrasah di beberapa negara Asia Tenggara mempunyai posisi unik, di samping sebagai tempat pengajaran dan pendidikan agama Islam lembaga ini ternyata juga menjalankan fungsi pendidikan formal. Penelitian ini ingin mengkaji posisi madrasah di salah satu negara Asia Tenggara, yaitu Filipina. Madrasah di Filipina awalnya dianggap sebagai bagian dari penyemaian ide separatisme bangsa Moro yang ingin memisahkan dari Filipina. Penelitian ini dilakukan dengan pendekatan studi kepustakaan, dengan tujuan melacak sejarah dan perlakuan pemerintah Filipina terhadap lembaga pendidikan jenis ini. Hasil penelitian menunjukkan bahwa pemerintah Filipina mulai mengakomodasi lembaga pendidikan madrasah dalam sistem pendidikan nasional mereka.
\end{abstract}

Kata Kunci: Islam, madrasah, kolonialisme, Filipina 


\section{PENDAHULUAN}

Sejak peristiwa serangan teror 11 September 2001 di menara Word Trade Center (WTC) Amerika Serikat yang konon dihubungkan dengan organisasi Al Qaedah yang berpusat di Afghanistan telah menyebabkan munculnya pandangan bahwa lembaga pendidikan Islam seperti madrasah pantas dicurigai menjadi tempat reproduksi ekstremis muslim yang berani melakukan tindakan teror seperti itu. Pandangan generalisasi bahwa semua madrasah di Negara-negara muslim juga berpotensi menjadi tempat melahirkan orang-orang ekstrem adalah pandangan yang menyederhanakan masalah. Generalisasi seperti itu tidaklah tepat dan bijaksana dalam melihat madrasah di semua negara tanpa melihat kultur lokal yang mungkin mewarnai. ${ }^{1}$

Gambaran madrasah di Afghanistan yang memang cenderung hanya mengajarkan pendidikan agama dan tidak berfungsi sebagai lembaga pendidikan formal sebagaimana madrasah di Indonesia, tidak tepat apabila gambaran seperti itu ditimpakan kepada madrasah di negeri lain. Madrasah di Indonesia sampai saat ini telah mengalami proses yang panjang, madrasah telah bermetamorfosis dari lembaga

1 Azra menyebutkan bahwa karakteristik madrasah di berbagai kawasan mempunyai warna berbeda. Di Mesir, madrasah telah dinasionalisasi sepenuhnya oleh pemerintah Presiden Nasser pada tahun 1960-an sehingga sepenuhnya menjadi 'sekolah umum' untuk tidak menyebut sekolah 'sekuler'. Di Turki, madrasah telah dihapuskan sama sekali sejak 1920-an oleh Kemal Ataturk diganti dengan sekolahsekolah sekuler. Di India dan Pakistan, madrasah enggan disentuh oleh Negara, sehingga pada gilirannya tetap berada dalam alam tradisionalisme. Azra, Azyumardi. 2005 dalam makalah "Pendidikan Pesantren dan Tantangan Perubahan" dalam prosiding yang dikoleksi PPIM, Jakarta. pendidikan yang semula hanya mengajarkan pendidikan agama saja menjadi lembaga pendidikan formal yang juga mengajarkan pelajaran umum sebagaimana sekolah yang diakui Undang-Undang (UU No. 20 tahun 2003).

Demikian juga madrasah di Filipina, semula madrasah di Filipina dipahami sebagai bagian dari tradisi pendidikan yang dimiliki umat Islam di Filipina Selatan yang sejak awal ingin memisahkan diri dari Filipina. Umat Islam di wilayah Filipina sejak pasukan Spanyol berhasil menaklukkan kerajaan Islam Manila (1571) hingga kini belum tuntas membuat penyelesaian politik yang memuaskan semua pihak. Semula bangsa Moro itu lebih memilih mendirikan negara sendiri, namun pemerintah Filipina tidak mau memenuhi permintaan itu. Karena itu, dalam upaya membujuk umat Islam Filipina agar bersatu membangun negara, pemerintah Filipina berupaya dengan segala macam cara untuk mengintegrasikan bangsa Moro dan wilayah yang dikuasainya dalam kesatuan negara Filipina. Bagaimana pemikiran pemerintah Filipina terkait salah satu lembaga pendidikan Islam bernama madrasah di negeri itu? Tulisan ini mencoba membahasnya.

Penelitian ini dirumuskan untuk menjawab bagaimana perkembangan pendidikan madrasah di Filipina. Untuk memahami konteks permasalahan, pertanyaan penelitian dirinci dengan pertanyaan kecil: bagaimana konteks sejarah Islam sebagai latar belakang madrasah di Filipina, Bagaimana penyelenggaraan madrasah di Filipina, dan bagaimana peluang yang bisa dikembangkan antara Indonesia dengan Filipina dalam memajukan madrasah. 
Penelitian ini termasuk penelitian kualitatif. Pendekatan yang dipakai adalah penelitian murni kepustakaan (library research). Data diperoleh dari bahan bacaan yang diperoleh peneliti dari buku-buku, artikel-artikel yang termuat dalam cetak buku ataupun cetak elektronik (internet). Data dikumpulkan dan dipilah-pilah untuk mengisi jawaban dari pertanyaan penelitian yang dirumuskan. Analisa menggunakan pendekatan analisis isi (content analysis) yang disesuaikan dengan kebutuhan menyusun keterkaitan historis dan konteks dinamika madrasah di Filipina.

Dalam konteks Negara, Ickhen Safa menyebutkan peran pendidikan dalam proses modernisasi dan integrasi nasional. Proses 'national building' meliputi konsolidasi tidak hanya pada aspek material, tetapi juga dalam wilayah ideologis, penekanan tidak hanya pada usaha mobilisasi dan pengembangan sumber-sumber daya yang dimiliki Negara melainkan juga usaha pencapaian pada konsensus ideologis yang mengikat orang dalam kebersamaan nilainilai dan tujuan. ${ }^{2}$ Ickhen Safa mengutip

${ }^{2}$ Dalam memaparkan tulisan ini, Ickhen Safa selain mengutip beberapa teori, dia menggunakan pendekatan komparasi antara dua penelitian kasus tentang posisi pendidikan dalam perubahan sosial. Dua penelitian yang dilakukan oleh Manning Nash (1965), yaitu tentang desa tertutup di Amatenango, Meksiko dengan desa Cantel di pegunungan Guatemala. Kajian ini menyebutkan peran penting pendidikan dalam proses 'nation building', yaitu: 1) peran penting pendidikan dalam menjembatani antara komunitas tertutup dengan komunitas terbuka; 2) lembaga pendidikan yang berperan sebagai 'broker'; 3) dalam menjalankan peran pendidikan diperlukan tambahan institusi pendukung pada sekolah; 4) pentingnya dukungan pemerintah. Dalam Safa, Helen Ickhen, 1971 "Education, Modernization, and the The Proses of National Integration," dalam Anthropological Perspectives on Education (edit by Murray Wax et al.). New York: Basic Books, Inc, h. 224-228. salah satu antropolog yang peduli terhadap tema 'nation building' yaitu Julian Steward (1950, pp. 107-108) yang menyatakan bahwa proses integrasi sosiokultural tidaklah hanya penyatuan sejumlah dan perbedaan aspek-aspek masyarakat, tetapi juga pada perkembangan fungsi interdependensi antar aspek itu. Dalam masyarakat kompleks, fungsi interdependensi diperankan melalui kelompok-kelompok sosial tertentu, yang disebut Steward sebagai segmen horizontal, dan melalui institusi-institusi formal Negara. Segmen-segmen horizontal itu meliputi kelompok-kelompok pekerjaan, kelas, kasta, ras, atau etnik yang melampau lokalitas dan mengikat komunitas-komunitas itu dalam subkultur-subkultur nasional baru. Institusi-institusi formal Negara itu bisa berupa keuangan, perbankan, perdagangan, sistem legal, tentara, konstitusi agama yang menciptakan masyarakat bersama dalam level nasional.

Negara melakukan pendidikan secara kolektif atau massal. Thomas F. Green (1971) mengajukan pertanyaan: sebenarnya pendidikan massal itu untuk apa? Untuk kewargaan atau untuk kebutuhan sertifikasi? Dalam menjawab pertanyaan ini, Green menggunakan pendekatan historis dalam menggambarkan fungsi pendidikan, dia juga melakukan kritik di mana pendidikan tidak semata-mata berfungsi sebagai pendidikan kewargaan (citizenship) tetapi juga mempunyai fungsi lain. Berangkat dari permasalahan tersebut, Green kemudian mengembangkan tipologi bahwa pendidikan melayani dua kepentingan, yaitu: Pertama, merujuk Jeferson yang menyatakan bahwa fungsi paling fundamental dari pendidikan adalah berkaitan dengan pembangunan kewarganegaraan, pendidikan adalah usaha 
untuk membuat kesadaran menjadi warga yang demokratis. ${ }^{3}$ Kedua, selain sebagai pendidikan kewargaan Green mengemukakan kenyataan bahwa pendidikan juga berfungsi untuk memenuhi kebutuhan sertifikasi kemampuan sebagai bahan pertimbangan untuk pemenuhan dunia pekerjaan.

Madrasah sebagai salah satu jenis pendidikan yang ada di wilayah Filipina tentunya tidak bisa hanya dituduh menjadi tempat penyemaian paham separatis. Berangkat dari pengalaman Indonesia, madrasah bisa menjadi tempat penyemaian paham agama yang moderat, yang cocok dalam membangun gagasan kebangsaan. Azra (2005) menyebutkan Dale Eickelman, seorang antropolog terkemuka di Amerika Utara, berpandangan bahwa madrasah di Indonesia adalah model yang menarik yang berbeda dengan madrasah di Negara lain. Azra menyebutkan bahwa karakteristik madrasah di berbagai kawasan mempunyai warna berbeda. Di Mesir, madrasah telah dinasionalisasi sepenuhnya oleh pemerintah Presiden Nasser padatahun 1960-an sehingga sepenuhnya menjadi ‘sekolah umum' untuk tidak menyebut sekolah 'sekuler'. Di Turki, madrasah telah dihapuskan sama sekali sejak 1920-an oleh Kemal Ataturk diganti dengan sekolah-sekolah sekuler. Di India dan Pakistan, madrasah enggan disentuh oleh Negara, sehingga pada gilirannya tetap berada dalam alam tradisionalisme

3 Menurut Green (1971), dalam konteks ini, pendidikan mempunyai tiga fungsi fundamental: (a) tempat sosialisasi; (b) transmisi kebudayaan; (c) pengembangan identitas individu. Green, Thomas F., 1971 "Citizenship or Certification" dalam Anthropological Perspectives on Education (edit by Murray Wax et al. ), New York, Basic Books, Inc, Publisher. H. 129143.
Eickelman melihat betapa strategisnya kebijakan pemerintah Indonesia dalam memelihara keberlangsungan madrasah, sementara pada saat yang sama melakukan berbagai langkah untuk menjembatani 'ideologi' Islam dengan kerangka common platform Negara bangsa Indonesia, yaitu Pancasila. Eickelman melihat di Indonesia, madrasah mengalami kontekstualisasi terus menerus sesuai dengan perkembangan zaman, madrasah tidak lagi menjadi penghambat bagi modernisasi.

Penulis dalam disertasi di Universitas Indonesia membuat analisis bahwa dari praktik pendidikan agama di tiga jenis pendidikan yang ada di Indonesia, yaitu sekolah umum, madrasah dan sekolah umum Islam, ternyata masing-masing mempunyai potensi kecenderungan yang berbeda. Pada sekolah umum dimungkinkan karena tidak ada target dan tekanan ideologi keagamaan tertentu, memungkinkan anak didiknya paham agama secara datar-datar saja dan potensial permisif karena tidak ada pagar ideologi keagamaan tertentu. Pada siswa sekolah umum Islam yang disponsori oleh keagamaan tertentu seperti organisasi Islam Muhammadiyah atau Partai Islam tertentu, potensial anak didiknya mempunyai karakter ideologi keagamaan tertentu. Sedangkan pada siswa madrasah, karena jenis pendidikan ini kurikulumnya di standarkan oleh negara, maka anak didiknya cenderung moderat dan jarang terjebak pada paham keagamaan yang ekstrem. ${ }^{4}$

${ }^{4}$ Muhamad Murtadlo. "Madrasah dalam Konteks Globalisasi Pendidikan” (Disertasi), Depok: Universitas Indonesia, 2012, h. 224. 


\section{PEMBAHASAN}

\section{Islam dalam Lintasan Sejarah Filipina}

Islam pernah menjadi agama mayoritas di Filipina sebelum kolonialisme bangsa Barat masuk ke wilayah itu. Islam masuk ke wilayah Filipina diperkirakan sudah terjadi pada tahun 1300-an. Sebuah batu nisan atas nama Miqbal, dengan tahun 1310, ditemukan di Badatto, tidak jauh dari Jolo, Pulau Sulu. Penemuan batu nisan inilah yang dijadikan salah satu bukti arkeologis masuk dan berkembangnya Islam di Filipina. Pada waktu itu masyarakat Pulau Jolo masih menyembah berhala dan animisme.

Tokoh penting lain yang biasa disebut sebagai perintis Islam di Filipina adalah Sharif Karim Al Makhdum yang berdakwah melalui penguasaannya terhadap ilmu-ilmu gaib, pengobatan dan semacamnya. Dia dikatakan tinggal di ibukota lama, Bwansa. Di sana dia membangun masjid dan orangorang berduyun-duyun ke sana. Salah seorang kepala suku dikabarkan masuk Islam. ${ }^{5}$

Perintis yang lain ada nama Tuan Masha'ika. Kelebihan Tuan Mashaika ini adalah dia dengan mudah diterima dan dihargai oleh masyarakat setempat, bahkan kemudian menikah dengan seorang putri Rapa Sipad. Tuan Masha'ika berputra tiga orang, seorang bernama Aisha, Tuan Hakim (berputra empat orang laki-laki Tuan Da'im, Tuan Buda, Tuang Bujang dan Tuan $\mathrm{Muku}$ ), dan seorang lagi putri yang tidak dikenal namanya. Keempat putra dari Tuan

${ }^{5}$ De Graaf, Islam di Asia tenggara Sampai Abad ke 18 dalam Perspektif Islam di Asia tenggara (Penyunting: Azyumardi Azra), Jakarta: Yayasan Obir Indonesia, 1989. H. 8
Hakim (berarti cucu dari Tuan Masha'ika) memerintah di Maimbung.

Sejak itu perkembangan islam menyebar ke tempat-tempat penting di Filipina. Begitu jayanya, Islam pernah menjadi agama mayoritas di Filipina dengan ditandai dengan kehadiran kerajaankerajaan Islam yang berkuasa seperti Kerajaan Manila (1500-1571) di bagian utara Filipina atau di Pulau Luzon, kerajaan Sulu dan Kerajaan Manguindanau di bagian Selatan Filipina. Kehadiran kolonialisme di Filipina (khususnya Spanyol) telah menggeser pengaruh Islam di negeri itu dan menggantinya dengan agama Katolik. Sejak itu jumlah umat Islam di Filipina tergerus hingga saat ini tinggal kurang lebih $5 \%$.

Berikut kita coba deskripsikan secara selintas kehadiran sejarah Islam di Filipina pada masa lalu hingga perkembangan Islam di masa kini. Deskripsi Islam di Filipina dimulai dari deskripsi Islam pada masa Kerajaan Islam Manila, Kerajaan Islam Sulu, Kerajaan Islam Manguindanao. Dilanjutkan peran kolonialisme dalam dinamika Islam di Filipina, dimulai zaman Spanyol, zaman Amerika dan zaman Jepang. Setelah itu, digambarkan sedikit tentang Islam pada masa awal setelah Filipina merdeka hingga perjanjian Tripoli (1976), perjanjian kedua Filipina dan MNLF (1996) dan terakhir perjanjian antara Pemerintah Filipina dengan MILF, sayap lain dari perjuangan Moro yang awalnya ingin memisahkan diri dari Filipina.

Kerajaan Islam Manila (15001571) (juga disebut Kota Seludong), yang merupakan ibukota Filipina sekarang. Kerajaan ini merupakan gabungan kerajaankerajaan Islam yang pernah memerintah 
kawasan Manila, Filipina. Carmen A. Abubakar menyebutkan bahwa Islam di Pulau Luzon dikenalkan melalui peran kerajaan Brunai. ${ }^{6}$ Pada pertengahan abad ke 16, terdapat tiga raja yang memerintah kawasan ini. Mereka adalah Raja Sulaeman, Raja Matanda dan Raja Lakandula. Manila saat itu adalah negeri Islam paling utara di Nusantara dan telah menjalin hubungan dengan kesultanan Brunei, Kesultanan Sulu dan Kesultanan Ternate. Mengingat kerjaan Islam Manila adalah kerajaan Islam yang paling muda di antara kerajaan Islam yang lain di wilayah Filipina, nampaknya Spanyol nantinya mengincar menaklukkan kerajaan ini terlebih dahulu dalam menguasai Filipina. Maka pada tahun 1571. Kerajaan Islam Manila hancur dan berakhir. Semenjak itu Filipina bagian utara dijadikan wilayah basis yang selanjutnya orang lokal yang berhasil dikristenkan diajak memerangi Muslim di Filipina Selatan.

Kerajaan Sulu (1450-1917). Kerajaan ini berada di Filipina bagian Selatan yang berdiri pada tahun 1450. Pada waktu itu, seorang Arab dari Johor yaitu Sharif ulHashim Syed Abu Bakr tiba di Sulu. Ia kemudian menikah dengan Paramisuli, putri Raja Bagindo. Setelah kematian Raja Bagindo, Abu Bakr melanjutkan pengislaman di wilayah ini. Pada tahun 1457, ia memproklamirkan berdirinya Kesultanan Sulu dan memakai gelar "Paduka Maulana Mahasari Sharif Sultan Hashim Abu Bakr". Gelar "Paduka" adalah gelar setempat yang berarti tuan sedangkan "Mahasari" bermaksud Yang Dipertuan.

${ }^{6}$ Carmen A Abubakar. "The Advent and Growth of Islam in The Philippines" dalam Islam in Southeast Asia. (Singapore: Iseas, 2005). h. 50-51.
Pada zaman kegemilangannya, negeri ini telah meluaskan perbatasannya dari Mindanao hingga bagian timur negeri Sabah. Dalam Kakawin Nagarakertagama, negeri Sulu disebut Solot, salah satu negeri di kepulauan Tanjungnagara (KalimantanFilipina) yaitu salah satu kawasan yang menjadi daerah pengaruh mandala kerajaan Majapahit di Nusantara. Negeri Sulu terletak di lepas pantai timur laut pulau Kalimantan.

Kesultanan Manguindanau (12031888). Sebuah pemerintahan Melayu Islam yang memerintah sebagian Mindanao di Filipina selatan. Pengaruh kesultanan ini berkembang dari semenanjung Zamboanga ke teluk Sarangani. Di masa keemasannya, kesultanan ini memerintah seluruh Mindanaon dan juga pulau-pulau yang berdekatan. Shariff Mohammed Kabungsuwan dari Johor memperkenalkan agama Islam di tanah ini pada abad ke-12. Ia kemudian menikah dengan puteri setempat dan mendirikan Kesultanan Maguindanao pada sekitar tahun 1203 hingga 1205. Kesultanan ini pada mulanya beribukota di kawasan Cotabato. Kesultanan ini jatuh ke tangan Spanyol dan akhirnya menjadi sebagian dari Filipina.

Pengaruh Islam di Filipina seiring dengan keberhasilan Spanyol menguasai daerah itu Islam selanjutnya menjadi agama yang tergusur. Hal itu diperparah dengan kehadiran penjajah berikutnya. Berturut-turut penjajah menguasai Filipina, yaitu Spanyol (1571-1896), Amerika (18981942) dan Jepang (1942-1945). Orang Eropa pertama yang datang ke Filipina adalah Magellan pada 1521. Beliau berbangsa Portugis dan kemudian bergabung dengan Spanyol. Magellan mati dibunuh oleh penduduk Cebu, karena ikut campur dalam 
peperangan dengan penduduk lokal, sedang sisa pasukannya kembali ke Spanyol. ${ }^{7}$

Penjajahan Spanyol. Merasa menemukan daerah baru, setelah kegagalan Magellan, Spanyol berusaha memperjelas penguasaan atas bumi Filipina ini, maka kerajaan Spanyol segera mengirimkan pasukan kembali ke Filipina. Pada 1564 kerajaan Spanyol mengirim satu rombongan pasukan di bawah pimpinan Maguel Lopez da Legazpi bersama 6 orang misionaris Kristian, dan tiba di Cebu hujung tahun itu. Pada 1571, pasukan Legazpi berhasil menaklukkan kerajaan Islam Manila. Mulai saat itu, maka penjarahan dan penjajahan terhadap Filipina oleh Spanyol berlangsung sampai datangnya tentara Jepang dan kemudian Amerika Serikat, selama lebih kurang 300 tahun

Penjajahan Amerika(1898-1942).Spanyol sebenarnya tidak sepenuhnya berhasil menundukkan Mindanao dan Sulu, namun Spanyol tetap menganggap kedua wilayah itu merupakan bagian dari teritorialnya. Merasa di bawah klaimnya, spanyol pada saat menjual Filipina kepada Amerika Serikat seharga US \$20 juta pada tahun 1898M menyertakan wilayah Mindanau dan Sulu melalui traktat Paris. Sejak itu kedua kesultanan itu berada di bawah penguasaan Amerika. Awalnya, Amerika menampilkan diri sebagai sahabat yang baik dan dapat dipercaya. Mereka menjanjikan kebebasan beragama, kebebasan mengungkapkan pendapat, kebebasan mendapatkan pendidikan bagi bangsa Moro dengan bukti penandatanganan Traktat Bates (20 Agustus

${ }^{7}$ Saifullah SA. "Umat Islam di Filipina Selatan: Sejarah, Perjuangan dan Rekonsiliasi” dalam Jurnal Islamica, Vol. 3, No. 1, September 2008
1898). Tetapi tampaknya hal itu hanya taktik meredam perlawanan umat Islam, karena pada saat yang sama AS menghadapi penolakan dan perlawanan di wilayah utara. Begitu perlawanan kelompok revolusioner utara dapat mereka kalahkan pada tahun 1902, kebijakan AS di Mindanao dan Sulu berubah menjadi politik campur tangan dan penjajahan terbuka.

Selama masa perjanjian itu pula AS berhasil membuka sejumlah daerah dan hutan untuk kepentingan kapitalis. Pada tahun 1903 Mindanao dan Sulu dijadikan satu wilayah dengan nama Moroland. Tindakan Amerika ini mendapat perlawanan kaum Muslimin, lebih dari empat puluh kali pertempuran terjadi antara tahun 19031923. Amerika tidak berhasil menaklukkan kaum Muslim Moro dengan kekuatan militer. Mereka akhirnya menerapkan strategi penjajahan melalui pendidikan dan bujukan, yang kemudian mereka jadikan sebagai kebijakan di seluruh jajahan mereka. Sebagai dampaknya kesatuan politik dan persatuan masyarakat Muslim mulai berantakan, norma-norma Islam mulai diserang budaya-budaya Barat. Melalui strategi ini Amerika memasukkan kebiasaan dan tradisi orang-orang Kristen ke dalam masyarakat Muslim. Selain itu Amerika juga bermaksud menggabungkan kaum Muslim ke dalam arus utama masyarakat Filipina Utara yang Kristen.

Pendekatan ini sedikit demi sedikit mengurangi dan melemahkan kekuasaan politik para Sultan. Amerika kemudian mengalihkan kekuasaan mereka kepada Kristen Filipina di utara. Kekuasaan para Sultan secara bertahap diambil alih oleh Manila. Kemudian melalui berbagai kebijakan dan perundang-undangan agraria 
pemerintah Manila mempersempit wewenang kaum Muslimin Moro khususnya para Sultan dalam kepemilikan tanah, sebaliknya memberikan keleluasaan kepada orang-orang utara dan para kapitalis untuk menguasai tanah Mindanao dan wilayah kepulauan selatan lainnya.

Terjadilah pertempuran berdarah antara muslim Mindanao dengan penjajah AS yang berakhir dengan perjanjian antara Sultan Mindanao dengan AS yang dikenal dengan "Treaty Bates" pada 22 Agustus 1899. Perjanjian ini tidak bertahan lama, karena tiba-tiba pada tahun 1902, AS menganeksasi wilayah Mindanao ke dalam pembentukan Filipina. Pada tahun 1940, AS menghapuskan kesultanan dan kawasan Mindanao dimasukkan ke dalam sistem administratif Filipina. ${ }^{8}$

Penjajahan Jepang (1942-1945). Seperti pada umumnya negara-negara Asean yang sempat dikuasai oleh Jepang, Islam tidak mengalami perubahan yang banyak, karena begitu Jepang kalah dengan sekutu pada tahun 1945 peta politik di Filipina kembali seperti sebelum Jepang datang, di mana Sulu dan Mindanau di Filipina Selatan telah diklaim dalam satu teritori politik Filipina yang terpisahkan.

Filipina Merdeka. Filipina mendapatkan kemerdekaannya dari Amerika pada tanggal Juli 1946. Konsolidasi politik antara Filipina Utara dengan Filipina selatan yang diwariskan oleh Amerika kepada pemerintahan baru Filipina belum atau tidak memuaskan kelompok Islam di Selatan.

8 Perjanjian Damai Akhir Cerita Perjuangan Bangsamoro?. http://syamina.org/ syamina21Perjanjian-Damai-Akhir-Cerita-PerjuanganBangsamoro-.html. Akses 11 Juli 2012
Akibatnya selama masa kemerdekaan hingga tercapainya perjanjian Tripoli 1976 antara Pemerintah Filipina dengan MNLF sering terjadi kontak senjata antara dua kekuatan itu.

Pada tahun 1972 Presiden Marcos menetapkan keadaan darurat yang diberlakukan untuk mengatasi memburuknya pelaksanaan hukum. Masyarakat baru yang ingin dibangun oleh Marcos merupakan upaya untuk memperbaiki kebobrokan yang melanda Filipina sebagai negara. Kaum Muslim tentu saja terpengaruh; namun pada tingkat pemerintahan mereka telah diberi konsesi. Pemberontakan kaum Muslim dilihat sebagai sesuatu yang terlalu mahal dan tidak perlu. Perjanjian Tripoli yang diupayakan untuk menghentikan pertempuran antara pihak Moro National Liberation Front (MNLF) dengan pemerintah Filipina diadakan. Langkah-langkah positif telah dilakukan pemerintah untuk menunjukkan perhatian dan iktikad baik. Di antaranya adalah dengan pembentukan Filipine Pilgrimage Authority, yaitu agen pembangunan dan kesejahteraan Muslim dan pelaksanaan hukum keluarga bagi kaum Muslim.

Perjanjian Tripoli 1976, sekalipun masih menimbulkan penafsiran sepihak dan sering tidak memuaskan kelompok Islam, menjadi modal bagi Pemerintah Filipina untuk membangun teritori Negara yang tunggal dengan melibatkan kelompok Islam. Maka sejak itu Pemerintah Filipina mencoba mengakomodasi kepentingankepentingan kelompok Islam dengan salah satunya yang monumental adalah membentuk Kementerian Urusan Agama Islam, sebagaimana Kementerian Agama di Indonesia pada 28 Mei 1981. Kementerian 
ini bertugas menerapkan kebijakan yang menjamin penyatuan masyarakat Muslim ke dalam masyarakat Filipina secara keseluruhan. Salah satu program yang secara langsung berkaitan dengan masalah perekonomian umat Islam adalah didirikannya Philippine Amanah Bank. Bank ini merupakan kombinasi dari bank finansial, pembangunan komersial dan tabungan dengan sistem Islam dengan tujuan untuk membiayai dan melaksanakan pengembangan pertanian, pabrik, pertambangan, transportasi dan industri lainnya di wilayah Selatan.

Perjanjian Tripoli antara pemerintahan Filipina dengan MNLF sempat teronggok karena kelompok Islam masih diperlakukan tidak adil. Karena itu perjanjian antara Pemerintah Filipina dengan MNLF sempat diperbarui dengan komitmen baru pada tahun 1996. Namun diakui bahwa kekuatan utama kelompok Islam tidaksajadiwakilioleh MNLF, tetapi juga MILF. MNLF adalahgerakan yang dikepalai oleh Nur Misuari sebagai kelompok Muslim yang dominan yang telah pernah menandatangani perjanjian Tripoli 1976, dan terakhir kali MNLF memperbarui perjanjian damai dengan pemerintah pada tahun 1996. Moro Independence Islamic Front (MILF), yang awalnya berjuang untuk negara Muslim merdeka di bagian selatan Filipina, memisahkan diri dari MNLF setelah Misuari menandatangani pakta damai yang menciptakan Daerah Otonomi di Mindanao Muslim (Autonomous Region in Muslim Mindanao atau ARMM), yang meliputi Provinsi Sulu, Maguindanao, Lanao del Sur, Tawi-Tawi, dan Basilan, kecuali ibukotanya, Isabella.

Pada tahun 2012, akhirnya Pemerintah Filipina dan MILF mencapai terobosan besar dengan membuat "kerangka kerja perjanjian damai" untuk menghentikan konflik yang telah berlangsung hampir empat dekade di Mindanao dan menelan korban tewas lebih dari 120 ribu jiwa. Pemerintah Filipina dan MILF bertemu di istana kepresidenan pada tanggal 15 Oktober 2012 untuk menandatangani kerangka kerja tersebut, yang menjadi tonggak sejarah baru bagi perjuangan kaum muslimin selama kurun waktu 40 tahun di Pulau Mindanao. Perjanjian ini ditandatangani oleh pengacara Marvic Leonen, perunding utama pemerintah, dengan Mohagher Iqbal, utusan MILF. Perjanjian ini merupakan langkah terbaru dalam meyakinkan MILF untuk melepaskan tuntutannya atas negara merdeka, dan sebagai gantinya dibentuklah wilayah dengan otonomi lebih luas.

\section{Pendidikan Madrasah di Filipina}

Pemerintah Filipina walau agak lamban bertekad untuk menyatukan semua wilayah dalam konsep negara Filipina. Karena itu beberapa usaha mengintegrasikan umat Islam dalam politikFilipinaterus diupayakan. Beberapa perjanjian dilakukan antara pemerintah Filipina dengan kelompok Moro seperti Perjanjian Tripoli (1976), Perjanjian Filipina dengan MNLF (1996), terakhir perjanjian pemerintah Filipina dengan MILF (1912). Seiring berjalannya waktu, dalam rangka mengintegrasikan politik umat Islam dalam kerangka negara Filipina, Beberapa akomodasi dilakukan pemerintah Filipina untuk mengambil hati umat Islam.

Saifullah SA menginventarisir beberapa langkah Pemerintah Filipina dalam mengakomodasi kepentingan umat Islam itu antara lain: Pembentukan Pemerintah Regional yang otonom (Regional 
Autonomous Government/RAG); Pembentukan Kementerian Urusan Agama Islam (1981); Pembentukan Badan Pengelola Perjalanan Haji Filipina (1979); Mendirikan Institut Studi-studi Islam Universitas Manila (1973); Mendirikan King Faisal Centre for Islamic and Arabic Studies, Mindanao State University (1973); Pusat Studi Perdamaian Filipina Selatan (Southern Philippines Center for Peace Studies) tahun 1979; Melancarkan Philippines Amanah Bank dan Dana Pembangunan Muslim (1973). ${ }^{9}$

Sebagaimana tradisi Islam di kawasan Asia tengara, pendidikan Islam ditransmisikan melalui beberapa bentuk media pendidikan formal seperti melalui maktab atau madrasah, pendidikan nonformal melalui tempat ibadah seperti masjid, surau, pesantren dan pendidikan informal melalui pendidikan keluarga. Khusus mengenai madrasah, Informasi awal mengenai madrasah di Filipina disebutkan Pada tahun 1950 dua orang pendakwah dari Universitas Al-Azhar Cairo mesir Tiba di Filipina Selatan. Mereka membuka sebuah madrasah "AlKuliyat Al-Istihadiyah" di Malubung, Lanao de sur. Setelah satu tahun ditutup. Salah seorang pendakwah tersebut Toha Omar pindah ke Jalo, Sulu dan Menjadi kepala madrasah Islamiyah Sulu yang didirikan di bawah kepemimpinan Mayor Barley Abu Bakar. ${ }^{10}$

Sejak 1980-an, Pemerintah Filipina mencoba menyeriusi usaha akomodasi kepentingan Islam dalam sistem pemerin-

${ }_{9}$ Saifullah SA. "Umat Islam di Filipina Selatan: Sejarah, Perjuangan dan Rekonsiliasi” dalam Jurnal Islamica, Vol. 3, No. 1, September 2008, h. 65-68.

${ }_{10}$ Pendidikan Islam Di Asia Tenggara http:// kulimijit. blogspot.com /2010/03/pendidikan-islamdi-asia-tenggara.html. Akses 11 Juli 2012 tahan Filipina. Di mulai dengan pembentukan Kementerian Urusan Agama Islam, sebagaimana Departemen Agama di Indonesia, pada tahun 1981. Pemerintah Filipina juga mencoba menginisiasi usaha-usaha pengembangan pendidikan Islam.

Usaha di bidang pendidikan Islam Filipina antara lain menyelenggarakan Kongres Pertama Pendidikan Islam (27-31 Oktober 1980) di mana pembahasan dilakukan dengan pembagian 3 kelompok. Kelompok I (Pengelolaan dan Organisasi Madrasah), Kelompok II (Kurikulum, Pengajaran, Staf Pengajar dan Pelajar Madrasah), Kelompok III (Fasilitas Fisik dan Keuangan Madrasah). Kongres tentang pendidikan Muslim diadakan di Mindanao State University pada tanggal 27-31 Oktober 1980. Dan merupakan serial atau awal bagi beberapa kongres tentang pendidikan dan madaris berikutnya. Salah satu makalah penting adalah yang disajikan oleh Profesor Manaros Boransing, dengan judul Policy of Total development as an Aproach to the Bangsa Moro Problem: An Alternative to Autonomy. Di mana makalah tersebut kemudian diterima menjadi rekomendasi Kongres, yakni: a. Pemaduan suatu kurikulum 10 tingkat bagi pendidikan bahasa Arab/studi keislaman ke dalam sistem sekolah umum yang terintegrasi. b. Reorganisasi, pengangkatan dan pengukuhan madaris sebagai pusat-pusat pengajaran tingkat sekolah menengah, bagi studi-studi lanjutan dalam teologi Islam dan peradaban. c. Standardisasi dan pencetakan bahan-bahan pengajaran, khususnya buku teks, untuk kurikulum pendidikan Islam dan bahasa Arab. d. Program latihan singkat bagi guru dan pengelola pendidikan dalam bidang administrasi pengelolaan, bahasa Arab dan studi Islam. e. Pengorganisasian 
suatu yayasan swasta dalam pengumpulan dana untuk memulai atau melanjutkan kesinambungan pendidikan. f. Mempercepat program pemberian beasiswa bagi Muslim Filipina yang cerdas untuk melanjutkan studinya di semua bidang ilmu pengetahuan alam, teknologi dan kemasyarakatan. Disimpulkan, bahwa hanya dengan memberikan prioritas masalah pendidikan, membuka peluang dan kesempatan mendapatkan akses seluas-luasnya kepada dunia pendidikan, maka penyelesaian menyeluruh Umat Islam Filipina Selatan akan dapat diselesaikan. ${ }^{11}$

Setelah kongres Pendidikan Islam dilanjutkan dengan Menyelenggarakan Kongres Pertama Madrasah seluruh Filipina (2426 Mei 1982). Kongres ini diadakan di dan oleh Western Mindanao State University di Zamboanga City pada tanggal 24-26 Mei 1982, sebagai kelanjutan dari Kongres Pendidikan sebelumnya. Kongres Madrasah tersebut membahas: 1). Status madaris (jamak dari madrasah), 2). Isu-isu aktual dan masalahmasalah yang mempengaruhi madaris, 3). Bagaimana madaris dapat dikembangkan menjadi lembaga-lembaga yang lebih siap sebagai komponen yang aktif dalam sistem pendidikan Filipina. Lebih jauh lagi, pembahasan dipusatkan pada pengelolaan dan organisasi madaris, kurikulum, pengajaran, staf pengajar dan pelajar, fasilitas fisik, pembiayaan dan hal-hal lain yang berkaitan dengan madaris. Instruksi Presiden nomor 1221 tanggal 31 Maret 1982 itu sendiri berisi ajakan dan seruan

\footnotetext{
${ }^{11}$ Nagasura Madale, "Kebangkitan Kembali Islam dan Nasionalisme di Filipina", dalam Taufik Abdullah dan Sharon Siddique, Tradisi dan Kebangkitan Islam di Asia Tenggara, (Jakarta: LP3ES, 1988), h. 359-360, 371377.
}

untuk mengadakan berbagai program bagi pengembangan madaris, program-program yang mengukuhkan berbagai studi Islam di lembaga pendidikan tinggi dan penegakkan serta pengukuhan program mengajar dan belajar bahasa Arab. ${ }^{12}$

Profesor Ahmad Hassoubah, seorang peneliti senior Filipina setelah melakukan penelitian mendalam tentang madaris, dalam Kongres tersebut memberikan rekomendasinya, yang kemudian dikukuhkan menjadi rekomendasi Kongres sebagai berikut: a. Madrasah harus tetap menjadi sebuah lembaga Islam, karena mewariskan studi-studi Islam dan bahasa Arab kegenerasi berikutnya. Tidak perlu dinasionalisasikan. b. Pengajaran bahasa Inggris dan keterampilan harus dimasukkan ke dalam kurikulum. c. Harus diupayakan diupayakan peningkatan status, dan pengakuan (legalisasi dan akreditasi) madaris sebagai lembaga resmi. d. Harus diusahakan latihan dan peningkatan kecakapan serta wawasan guru-guru bahasa Arab di madaris. e. Menghasilkan bahan-bahan pelajaran bahasa Arab dan studi-studi Islam dengan bantuan pemerintah dan badan-badan luar lainnya. f. Para lulusan madaris yang diakui harus bisa diterima di berbagai universitas umum, dan g. Menyusun standar profesional bagi para guru bahasa Arab

Memang kongres saja belum cukup. Seiring waktu konsolidasi politik Islam dalam pemerintahan Filipina dari pasca perjanjian Tripoli (1976) belum memuaskan semua pihak. Sejauh itu rekomendasi baru sebatas rekomendasi. Potensi pendidikan di madrasah di Filipina sebenarnya cukup besar. Carmen A Abubakar menyebutkan

\footnotetext{
${ }^{12}$ Nagasura Madale ....h. 358-359.
} 
pada tahun 1999 di Filipina terdapat 1.581 madrasah. ${ }^{13} \quad$ Gagasan pengintegrasian madrasah dalam sistem pendidikan Filipina baru menunjukkan tanda-tanda kemajuan setelah masuk tahun 2000-an.

Pada tahun 2004, Departemen Pendidikan mengadopsiDO 51 yang memasukkan pengajaran Bahasa Arab dan Nilai Islam di sekolah-sekolahumum,khususnyadidaerahdaerah Muslim. Kurikulum Pendidikan Islam dan Bahasa Arab untuk sekolah umum pertama kali diimplementasikan pada tahun ajaran 2005-2006, ${ }^{14}$ demikian juga di madrasah diujicobakan kurikulum standar atau yang sering disebut Standard Madrasa Curriculla (SMC) pada madrasah-madrasah yang umumnya swasta. Praktik yang sama diberlakukan pada sekolah-sekolah Islam, yaitu Sekolah Terpadu Ibnu Siena (Marawi), Sarang Bangun LC (Zamboanga) dan SMIE (Jolo). Sekolah-sekolah ini telah menjalankan kurikulum standar tersebut.

Sejak tahun 2005, AusAID memberikan pendampingan dalam kerangka proyek Departemen Pendidikan bagian Bantuan Pendidikan Dasar Mindanao/Basic Education Assistance for Mindanao (BEAM) telah membantu sekelompok madrasah swasta mencari izin pemerintah untuk mengoperasikan atau Permite to Operation (PTO) dan melaksanakan SMC.

Hingga saat ini, terdapat 30 dari swasta ini tersebar di seluruh Kawasan madaris XI, XII dan ARMM. SMC adalah kombinasi dari RBEC mata pelajaran (bahasa Inggris,

\footnotetext{
${ }^{13}$ Carmen A Abubakar. "The Advent and Growth of Islam in The Philippines" dalam Islam in Southeast Asia. (Singapore: Iseas, 2005). h. 50-51.

${ }^{14}$ Filipina Perkokoh Pendidikan Islam. http:// education-attache-manila.com/filipina-perkokohpendidikan-islam 12 Juli 2015
}

Filipina, Sains, Matematika dan Makabayan) dan pengajaran bahasa Arab dan studi Islam mata pelajaran.

- Daerah XI - Pilot Terpadu Madrasah (Davao Oriental), Al-Munawwara Sekolah Islam (Davao City)

- Region XII - WAMY Akademi (Gensan), Kumayl LC (Koronadal), Darul Uloom (Tamontaka, Cotabato City), Al-Nahdah Akademi (Campo Muslim, Cotabato City), Madrasah SKC Abubakar (Bagua, Cotabato City) dan Sultan Kudarat Akademi (Sinsuat Ave, Cotabato City)

- ARMM (Marawi City) - Jamiato Janoubel Filibbien, Jamiato Marawi al-Islamia, Khadijah Percontohan Madrasah, Putri Jawaher IS.

- ARMM (Lanao del Sur) - Ma'had Montashir (Masiu), Ma'had Aziziah dan Sha'rawi LC (Butig), Madrasah Al-Falah Khayrie (Lumba Bayabao), Ma'had Lanao (Malabang), As-Salihein Terpadu Sekolah (Tamparan), lain.

- ARMM (Maguindanao Valley) - Ibnu Taimiyah Academy (Shariff Kabunsuan), Ma'had Maguindanao (Ampatuan), Madrasah Datu Tahir (Mamasapano), Rahmanie Ma'had Al-Islamie (Sharif Aguak). Melalui Gubernur philanthopy Datu Andal Ampatuan dan keluarganya, Ma'had Rahmanie sedang dirancang ulang dan re-posisi itu dibangun untuk menjadi lembaga utama pembelajaran terpadu di ARMM. Ketika seluruh pembangunan infrastruktur selesai, maka akan berganti nama Shariff Ibnu Ampatuan Aguak Memorial Academy.

- ARMM (Pulau Provinsi) - Ma'had Dakwah (Lamitan Kota), Kulliyato Talipao (Talipao, Sulu), ANAK Madrasah (Bon- 
gao, Tawi-Tawi). The ANAK Madrasah adalah proyek khusus dan laboratorium sekolah dari MSU-TCTO College of Islam dan Arab Studies (CIAS).

\section{Prospek Pengembangan Kerjasama Madrasah Indonesia - Filipina}

Pasca pemerintah Filipina mengambil kebijakan memasukkan madrasah dalam sistem pendidikan Filipina, beberapa kali pemerintah Filipina berkunjung ke Indonesia untuk mempelajari model pendidikan Islam di Indonesia. Pada tahun 2010, Menteri Pendidikan Filipina, Br Armin A Luistro FSC, melakukan pertemuan dengan Menteri Pendidikan Nasional (Mendiknas) M Nuh di Jakarta. Pada kesempatan itu, Armin A Luistro menerangkan, alasan pihaknya untuk mengadopsi sistem pendidikan madrasah Indonesia tersebut, karena negara bekas jajahan Spanyol itu sudah membuka program pendidikan madrasah. ${ }^{15}$

Pada tanggal 8 Maret 2011, kunjungan itu ditindaklanjuti penandatanganan Memorandum of Understanding (MoU) di bidang Pendidikan Dasar antara Pemerintah Indonesia dan Pemerintah Filipina. MoU itu ditandatangani pada pada saat kunjungan Presiden Filipina ke Indonesia. Implikasi dari penandatanganan itu, Pemerintah Indonesia bersedia memberikan beasiswa S2 dan S3 kepada 23 guru madrasah di Mindanao. Para calon penerima beasiswa dapat memilih beberapa universitas untuk menempuh program tersebut yakni: Universitas Muhammadiyah Malang, Universitas Muhammadiyah Surakarta, Univer-

15 Filipina Ingin Adopsi Pendidikan Madrasah Indonesia, https:// z4muttaqien. wordpress. com/2010/11/30/ akses 12 juli 2015 sitas Muhammadiyah Jakarta, Universitas Muhammadiyah Prof. DR. Hamka Jakarta, Universitas Muhammadiyah Makassar, Universitas Muhammadiyah Yogyakarta, Universitas Ahmad Dahlan Yogyakarta, Universitas Islam Negeri Sunan Ampel Surabaya, Universitas Islam Negeri Surakarta. ${ }^{16}$

Melihat minat pemerintah Filipina dalam mengembangkan pendidikan madrasah, maka patutlah kita berbangga. Ada beberapa paket program pendidikan madrasah bisa ditawarkan berdasarkan pengalaman penyelenggaraan model-model madrasah di Indonesia. Beberapa program atau model penyelenggaraan madrasah yang menunjukkan keberhasilan antara lain: 1) Madrasah Aliyah Program Khusus (MAPK); 2) Madrasah Aliyah Boarding; 3) Madrasah Aliyah Program Keterampilan.

Model pertama yang bisa ditawarkan menjadi model adalah model pendidikan Madrasah Aliyah Program Khusus (MAPK) adalah program yang pernah digagas oleh Dr. Munawir Sadzali pada tahun 1987. Program ini berjalan 7 angkatan. Program ini dianggap sukses karena lulusannya yang diproyeksikan menjadi ulama yang cendekiawan atau cendekiawan yang ulama berhasil menjadi akademisi yang berhasil dan menduduki posisi stategis baik di Perguruan Tinggi Negeri maupun birokrasi pemerintahan. Sebagian lagi menjadi reseacher baik di dalam maupun luar negeri. ${ }^{17}$ Model ini sangat cocok bagi Filipina

${ }^{16}$ Beasiswa Indonesia Untuk Guru Madrasah Di Mindanao 2012. http://www. kemlu.go.id/davaocity/ Lists/EmbassiesNews/DispForm.aspx? Akses 11 Juli 2012

${ }_{17}$ Model ini di Indonesia sebenarnya dikembangkan menjadi Madrasah Aliyah Keagamaan (MAK). Namun ketika model ini dimassifikasi, ternyata 
yang menggagas kelompok pemikir Islam yang bisa menerima konsep negara modern Filipina yang bersatu. Dengan perhatian dan sponsor dari negara diharapkan lahir pemikir-pemikir yang moderat yang lebih berpikir kemajuan Filipina sebagai negara majemuk daripada berpikir menjadi agamawan yang separatis.

Model kedua yang bisa ditawarkan ke Pemerintah Filipina adalah model Madrasah Program Boarding. Di Indonesia, pengalaman madrasah program boarding ini sebenarnya pernah dilakukan ketika kementerian Agama RI menyelenggarakan MAPK. Namun madrasah program boarding lebih khusus modelnya ditujukan kepada piloting Madrasah. Pada tahun 1996 BJ Habibi dengan lembaga BPPT mencoba mendirikan Magnet school yang nantinya berubah namanya menjadi MAN Insan Cendekia di Serpong dan di Gorontalo. Program ini berhasil menghasilkan siswa-siswa yang bersaing di bidang sains umum sekalipun dibandingkan dengan siswa sekolah umum. Siswa-siswa madrasah model ini beberapa memenangi olimpiade sains baik nasional maupun internasional. ${ }^{18}$ Program ini bisa ditawarkan dengan pemerintah Filipina untuk mendongkrak daya partisipasi siswa Muslim dalam pembangunan nasional Filipina. Peran pemerintah yang tinggi dalam mensponsori kegiatan ini akan mengikat peserta didik dalam memajukan pembangunan nasional Filipina.

terjadi kualitas penyelenggaraan dan lulusan yang menurun. Model ini justru berhasil ketika dibuat khusus dengan jumlah satuan yang terbatas.

${ }^{18}$ Keberhasilan program ini, membuat kementerian agama berencana membuat Madrasah Insan Cendekia ini untuk setiap Provinsi di Indonesia.
Model ketiga yang bisa ditawarkan ke pemerintah Filipina adalah Madrasah Program Keterampilan. Program ini sebenarnya dalam nomenklatur perundangan sudah ada sebutan khusus yaitu Madrasah Aliyah Keterampilan (MAK). Madrasah program keterampilan yang pernah digagas Kementerian Agama adalah madrasah reguler yang didampingi laboraturium keterampilan. Program ini melahirkan anak didik yang skillfull yang siap mengisi dunia kerja. Kelebihan alumni Madrasah Program Keterampilan ini dibandingkan dengan alumni SMK adalah dalam hal sikap dan prilaku. Alumni madrasah program keterampilan biasanya lebih humbel, jujur dan berdedikasi. Model ini sangat cocok untuk Filipina yang menginginkan partisipasi rakyat muslim dalam pembangunan ekonomi. Keterserapan siswa muslim dalam dunia kerja akan lebih menguntungkan dalam keamanan nasional, daripada mereka menjadi pengangguran yang pada akhirnya berpotensi menjadi pembuat keonaran atas nama ideologi keagamaan.

Dari upaya penawaran tiga model ini ke pemerintah Filipina, pengalaman Kementerian Agama RI bisa dipercaya untuk terlibat langsung dalam kerja sama itu. Tentu saja pilihan model itu diserahkan sepenuhnya ke pemerintah Filipina dalam bentuk dan kuantitas kegiatan yang akan dikerjasamakan.

\section{PENUTUP}

Dari paparan tulisan ini ada beberapa kesimpulan yang digarisbawahi: 1) sejarah Islam di Filipina telah mengalami pasang surut dari agama yang pernah besar ditandai 
dengan kehadiran kerajaan Islam seperti Manila, Manguindanau dan Sulu menjadi kelompok umat minoritas yang disebabkan oleh kolonialisme yang dilakukan oleh Spanyol, Amerika dan Jepang. Hingga Filipina merdeka, identitas bangsa Filipina masih terbelah antara Filipina bagian utara dengan Filipina bagian Selatan; 2) untuk menyatukan identitas bangsa Filipina, pemerintah negara itu mencoba menyatukan bangsa Moro (Muslim) ke dalam identitas kebangsaan Filipina dalam berbagai perjanjian perdamaian seperti perjanjian Tripoli antara pemerintah dengan MNLF (1976), perjanjian itu diperbarui dengan perjanjian pemerintah Filipina dengan MNLF (1996) dan terakhir Perjanjian Pemerintah Filipina dan MILF (2012); 3) bersamaan dengan usaha pemerintah menyatukan politik bangsa Moro ke dalam bangsa Filipina, di bidang pendidikan pemerintah Filipina mencoba memasukkan sistem pendidikan Islam seperti madrasah dalam sistem pendidikan nasional. Ikhtiar itu dimulai dengan melakukan Kongres Pendidikan Islam I (1980) dan Kongres Pertama Madrasah (1982); 4) akomodasi pendidikan madrasah dalam sistem pendidikan Filipina mulai mengalami kemajuan sejak pemerintah Filipina mengadopsi DO 51 yang memasukkan pengajaran Bahasa Arab dan Nilai Islam di sekolah-sekolah umum, dan uji coba kurikulum standar atau yang sering disebut Standard Madrasa Curriculla (SMC) pada madrasah-madrasah swasta; 5) Pemerintah Filipina dalam mengembangkan pendidikan madrasah banyak belajar dari pengembangan madrasah di Indonesia. Pada tahun 2011, pemerintah Filipina dan pemerintah Indonesia membuat
Memorandum of Understanding yang memungkinkan Indonesia memberi bantuan beasiswa kepada guru-guru madrasah di Mindanao; 6) terkait dengan program pengembangan pendidikan madrasah di Filipina, Kementerian Agama Republik Indonesia perlu pro aktif dan mempelajari peluang kemungkinan kerja sama program dengan para pelaku madrasah di Filipina.

Penelitian ini merekomendasikan perlunya Kementerian Agama melalui Puslitbang Pendidikan Agama dan Keagamaanaktifmencermati perkembangan pengembangan madrasah di Filipina. Selain itu, perlu kiranya kementerian agama berinisiatif untuk menawarkan kerja sama program dengan pemerintah Filipina dalam melakukan pembangunan madrasah melalui program-program yang pernah berhasil diujicobakan di madrasah di Filipina seperti program MAPK, program madrasah boarding, program madrasah keterampilan, di samping kerja sama kegiatan dalam bentuk riset dan pengembangan. 


\section{SUMBER BACAAN}

Abubakar. Carmen A. (2005): "The Advent and Growth of Islam in The Philippines" dalam Islam in Southeast Asia. Singapore, Iseas

Azra, Azyumardi (2005): Pendidikan Pesantren dan Tantangan Perubahan. Makalah, PPIM.

De Graaf (1989): Islam di Asia tenggara Sampai Abad ke 18 dalam Perspektif Islam di Asia tenggara (Penyunting, Azyumardi Azra). Jakarta. Yayasan Obor Indonesia

Green, Thomas F. (1971): “Citizenship or Certification" dalam Anthropological Perspectives on Education (edit by Murray Wax et al.). New York, Basic Books, Inc, Publisher

Murtadlo, Muhamad (2012): Madrasah dalam Konteks Globalisasi Pendidikan (Disertasi). Depok, Universitas Indonesia

Madale,Nagasura (1988): “Kebangkitan Kembali Islam dan Nasionalisme di Filipina", dalam Taufik Abdullah dan Sharon Siddique. Tradisi dan Kebangkitan Islam di Asia Tenggara. Jakarta, LP3ES

Saifullah SA. (2008): "Umat Islam di Filipina Selatan: Sejarah, Perjuangan dan Rekonsiliasi" dalam Jurnal Islamica, Vol. 3, No. 1, September
Safa, Helen Ickhen (1971): "Education, Modernization, and the The Proses of National Integration, " dalam Anthropological Perspectives on Education (edit by Murray Wax et al.). New York: Basic Books, Inc,

Beasiswa Indonesia Untuk Guru Madrasah Di Mindanao 2012. http:// www.kemlu. go.id/davaocity/Lists/EmbassiesNews/ DispForm.aspx? Akses 11 Juli 2012

Filipina Ingin Adopsi Pendidikan Madrasah Indonesia, https:// z $4 \mathrm{~m} \mathrm{ut} \mathrm{ta} \mathrm{qi} \mathrm{e} \mathrm{n.w} \mathrm{or} \mathrm{d} \mathrm{pres} \mathrm{s.}$ com/2010/11/30/ akses 12 juli 2015

Filipina Perkokoh Pendidikan Islam. http:// education-attache-manila. Com / akses 12 Juli 2015

Perjanjian Damai Akhir Cerita Perjuangan Bangsa moro?. http://syamina.org/ syamina21- akses 12 Juli 2015 